\title{
Contributions of paleorheumatology to understanding contemporary disease
}

\author{
Contributo della paleoreumatologia alla conoscenza \\ della patologia osteoscheletrica dell'epoca contemporanea
}

\author{
B. Rothschild \\ The Arthritis Center of Northeast Ohio, University of Kansas Museum of Natural History, Carnegie Museum of Natural History, \\ Northeastern Ohio Universities College of Medicine and University of Akron
}

\begin{abstract}
RIASSUNTO
La paleopatologia è una disciplina che, a partire da semplici osservazioni, oggi si è spinta verso speculazioni sempre più raffinate, in virtù di tecnologie avanzate, che hanno aperto la via a nuove conoscenze sulla paleontologia dei vertebrati.

In presenza di modificazioni strutturali e densitometriche dell'osso, l'analisi radiografica, ed in particolare la fluoroscopia - tecnica semplice ed economica - può fornire moltissime informazioni, in grado di documentare la risposta dell'osso stesso alle sollecitazioni meccaniche ed in corso di varie condizioni patologiche. Ancora, la radiografia consente di "sezionare", in maniera non invasiva, i campioni, definendo così i dettagli interni non altrimenti esplorabili. Il materiale può essere anche sezionato sopra un piano, e le porzioni così ottenute a loro volta ruotate, tanto da "aprire" l'immagine (radiografia tridimensionale).

Nei reperti fossili, inoltre, possono essere perfettamente conservate le microstrutture ed il corredo antigenico. Ad esempio, l'ottimo grado di conservazione della struttura molecolare ad elica, con sensibilità alla collagenasi, è stato dimostrato in fibre collagene di materiale biologico risalente a 10 milioni di anni fa. Antigeni sono stati estratti da reperti ossei di 100 milioni di anni fa e rilevati "in situ” su materiali di 11.000 anni fa. Grazie all'impiego di antisieri specifici per determinati antigeni, si possono visualizzare reazioni di immunofissazione. Minime tracce di DNA possono anche essere amplificate e quindi analizzate. In questo modo sono stati identificati acidi nucleici di mammuth (40.000 di anni fa), bisonti (17.000 di anni fa) ed insetti (25 milioni di anni fa).

Le più moderne tecnologie, applicate alla paleopatologia, dimostrano, anche in prospettiva, quanto sia comunque importante un approccio multidisciplinare e collaborativo.
\end{abstract}

Reumatismo, 2002; 54(3):272-284

\section{INTRODUCTION}

A ccuracy of paleontologic perspectives, understanding disease states, hypothesis formation, and technology form the basis for this review. Moodie's (1) effort, in isolation, to attribute diagnoses to paleontologic observations were originally met with skepticism (Don Baird, personal and graphic communication) and have not stood the test of time $(2,3)$. Familarization with the technology should allow innovative approaches to mainstream

Address for correspondence:

The Arthritis Center of Northeast Ohio, 5500 Market Street, Youngstown, OH 44512, USA, E-mail bmr@neoucom.edu paleontologic questions. Collaborative efforts should allow avoidance of some of the pitfalls of that technology. When all parties to such collaboration must convince each other of the appropriateness of their "pronouncements," confidence is generated in the conclusions.

Generating testable hypotheses is the goal of disease analysis. [Perhaps a better term might be wellness analysis, as the number of healthy (paleontologic) individuals far exceeds the few "sick" ones]. While in the clinical setting, it certainly is fulfilling to "pronounce" a patient healthy, it is the pathologic paleontologic alterations which appear most amenable to habitat and lifestyle analysis. If the variety of responses of bone to any environmental factor is reproducible across phylogeny and 
chronology, identifying the cause of variations (from the normal condition) should be feasible. Delineating those physical conditions identifiable in bone, which are confirmable in etiology and distinguishable from diagenesis and other artifact is the initial focus.

\section{PATHOLOGIC CONDITIONS AFFECTING BONE}

Pathologic conditions amenable to identification in paleontologic specimens predominantly relate to bone and joint surfaces. While malignant bone tumors have been extremely rare $(4,5)$, hereditary forms of exostoses (bone overgrowths) have been found. Alterations in the outer layer of cortical bone (periosteal reaction) is rarely noted. While there are a multitude of causes for periosteal reaction, the nature and skeletal distribution may allow recognition of a specific diagnosis.

Diseases characterized by generalized alteration in bone density are difficult to assess because of the difficulty of controlling for diagenesis/taphonomy (post-mortem changes). Disorders producing osteopenia are typically not distinguishable in the absence of soft tissues. The major characteristic distinguishing osteoporosis and osteomalacia, for example, is presence of uncalcified osteoid tissue $(6,7)$. This is not generally assessable in paleontologic materials. However, osteopenia-producing disorders such as hyperparathyroidism may be associated with other alterations, which may suggest the diagnosis. Osteodystrophy (secondary hyperparathyroidism and osteomalacia related to renal failure) has been reported in non-human primates (8).

\section{PATHOLOGIC CONDITIONS AFFECTING JOINTS}

Identification of arthritis is based on the nature of bony (e.g., preservation of size and configuration, presence of erosion, reactive bone formation or remodeling), as well as soft tissue alterations (2, 6, 7). While bony alterations represent only a subset of those parameters, "defleshed" bones are frequently all that is available to the paleontologist. Most of the 200 varieties of arthritis are not known to produce any bony alterations $(2,6,7)$ and are therefore not amenable to paleontologic evaluation (with currently applied technology). This consid-

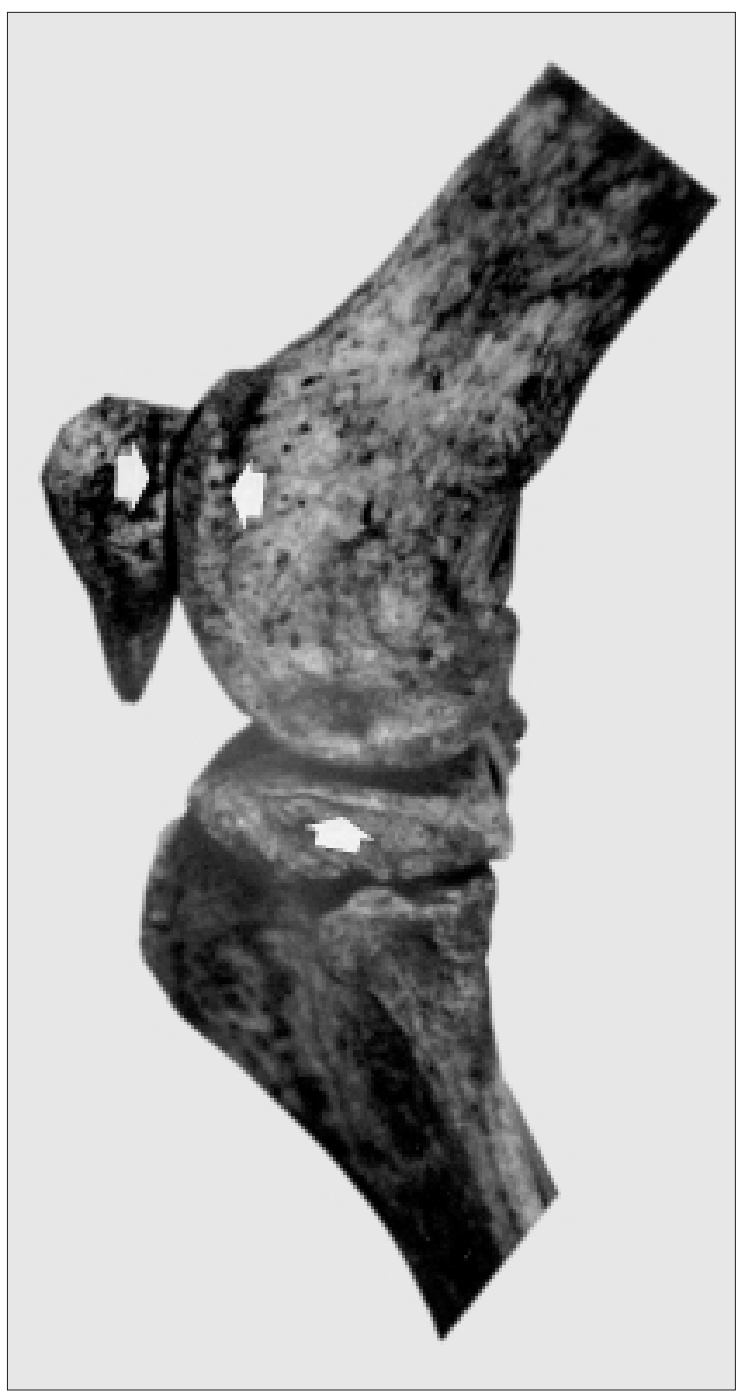

Figure 1 - Lateral view of Smiledon knee. Tibial, femoral, and patellar osteophytes (arrows) are present.

erably narrows the list of diagnoses recognizable in paleontologic specimens.

Arthritis is typically classified as erosive or nonerosive. One form of non-erosive arthritis is osteoarthritis. Bone remodelling occurs with spur (osteophyte) formation (Fig. 1). The density of the subchondral bone is increased and metaphyseal cysts may form (as recognized by $\mathrm{x}$-ray or crosssectional view). With increasing severity, the articular surfaces may even become grooved and eburnated. Extremely rare in dinosaurs [only two known examples (3)], it is more commonly noted in Quaternary mammals. Its analysis provides intriguing perspectives of "lifestyle" and habitat. The osteophytes of osteoarthritis must be distinguished 
from those of spondylosis deformans, the vertebral centra spuring phenomena. As the disc spaces are not diarthrodial joints, the term osteoarthritis is not appropriate for spine spuring, exclusive of zygoapophyseal joints.

\section{EROSIVE ARTHRITIS}

Erosive arthritis is recognized as disruption of cortical bone (Fig. 2), within or extrinsic to the joint capsule of diarthrodial joints (junction of hyaline cartilage-covered bone surfaces, at which movement occurs) (2, 6, 7). Intrinsic erosions (Fig. 3) are localized to subchondral (that portion of cortical bone to which articular cartilage is attached) or marginal regions (the metaphyseal cortical component located between cartilage-covered subchondral bone and the site of insertion of the joint capsule). As thirty to fifty percent of bone matrix must be lost before a lesion can be detected radiologically (7) most erosions recognized on gross examination of bones are not visible on specimen x-rays.

Artifacts must be excluded. Cracked and ragged edges, on the border of pseudo-erosions (artifacts) are readily discernable from the front of bone resorption more characteristic of erosive arthritis $(9,10)$. Plant roots, bacteria, fungi, protozoans, insects, snails and mammals often produce focal breakage, destruction and disturbance (11-16). Gnawing, producing linear U-shaped bands of crushed cortex or broad grooves, is usually highly characteristic and not easily confused with true erosions. Punctures wounds present as circular or elongated depressions with a perpendicular zone of jagged-edged cortical fragments (17).

A lytic lesion from which bone tissue has been removed by osteoclasts will present smooth, round-

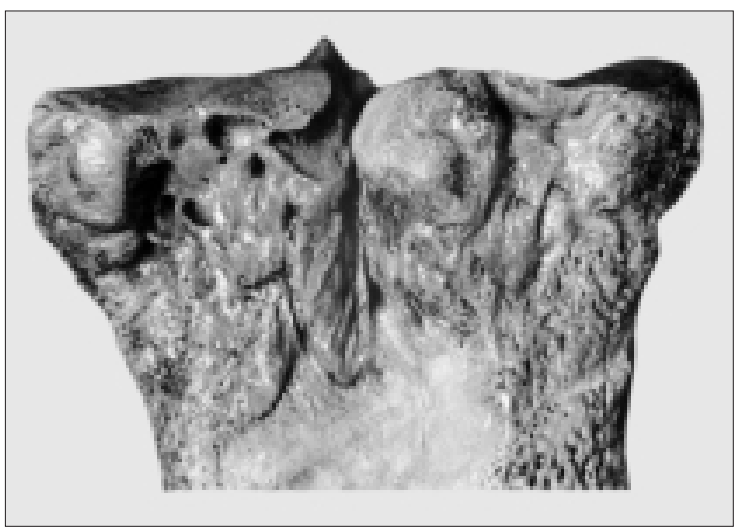

Figure 2 - Posterior view of proximal aspect of Bison knee (partial view). Left tibial plateau subchondral erosion is prominent. ed edges of any surfaces within and at the boundaries of the lesion; transitions from one plane of bone tissue to another will be smoothed. The edges of all exposed trabeculae, as in metaphyseal lesions, will appear smoothed, while intersecting planes of dense cortical bone will meet at a rounded edge. Although inflammation initially may activate osteoclastic resorption of peri-lesional trabeculae, it subsequently activates osteoblastic deposition in the same region. Thus, any trabecular edges initially exposed at the lesion boundary by osteolysis would subsequently appear thicker than trabecular edges revealed by post-mortem processes in the same region.

\section{Infectious arthritis}

Infectious arthritis is a form of erosive disease in which gross distortion of the joint surface and underlying bone (Fig. 4) is associated with reactive new bone formation $(3,6,7)$. It is usually limited in distribution, typically affecting only one joint. If the latter has a filigree appearance often bridging joint surfaces, the diagnosis of infectious arthritis is virtually assured. A combined sclerot-

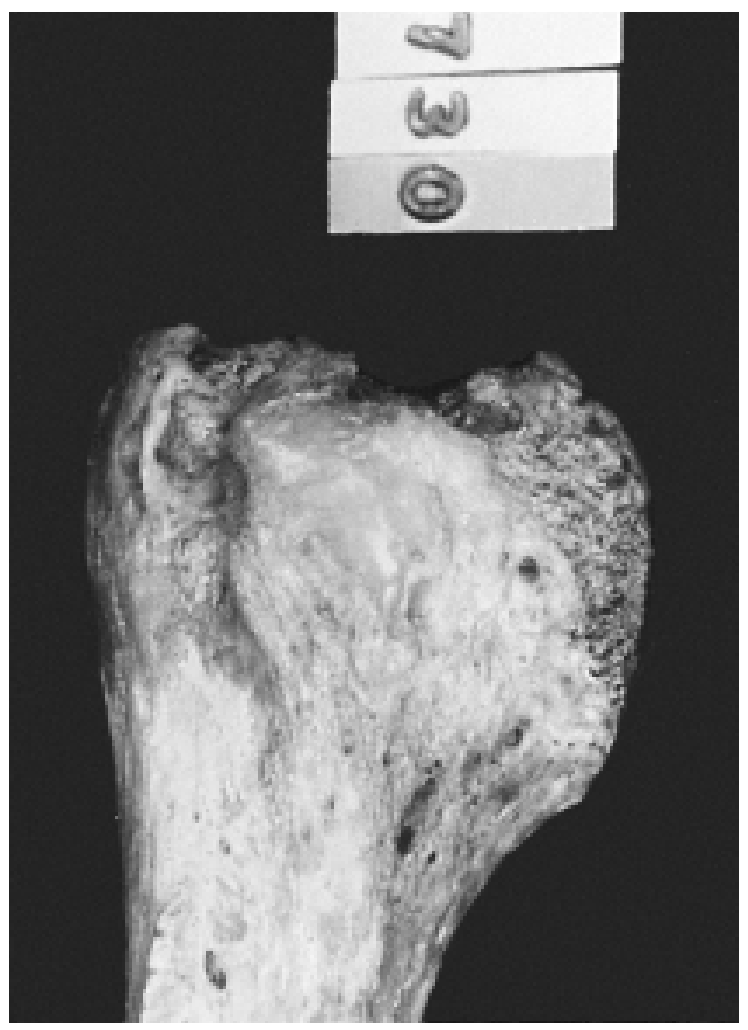

Figure 3 - Lateral view of human proximal humerus. Severe erosive disease, predominantly affecting subchondral bone. 


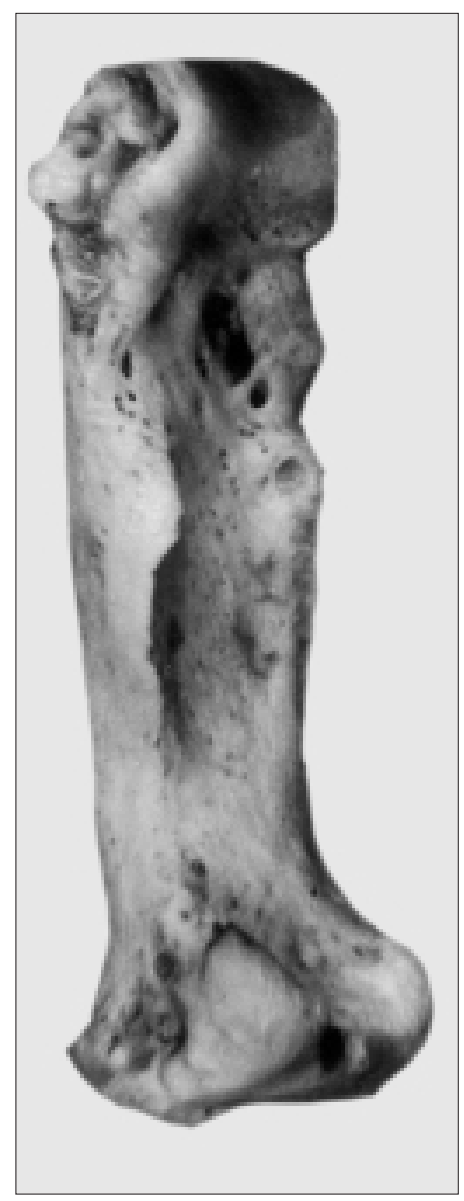

Figure 4 - Lateral oblique views of Gorilla metacarpal. Infection erosion and new bone formation distorts the architecture.

ic and resorptive picture is noted on cross-section or x-ray views. If the erosion appears to undermine subchondral cortical bone, without major destruction of the subchondral bone surface, tuberculosis is likely responsible $(3,6,7,18-21)$. Associated phenomena may facilitate diagnosis. The erosive lesions of syphilis are often associated with a characteristic spiculated periosteal reaction $(3,6,22,23)$.

Treponemal disease is recognized on the basis of periosteal reaction and osteitis. The appearance of individual bones and the nature and intensity of bone damage are similar in all three varieties known to afflict skeletal structures (22). However, the pattern of involvement is actually sufficiently disparate to allow distinguishing among them. Study of skeletal populations with yaws (in precontact Guam), bejel (in the 19th century Middle East) and syphilis (in 20th century Cleveland) allowed development of criteria, which have since proved reproducible in more than 40 archeologic populations $(22,24)$.

\section{Crystalline arthritis}

Gout erosions, caused by urate accumulation, are also associated with reactive new bone formation $(3,6,7)$. In contrast to the ill-defined margins of infectious arthritis, those of gout may be polyarticular and have a "punched out" appearance with a sclerotic margin. Overgrowth of peri-erosional bone forming an overhanging edge is considered pathognomonic $(3,6,7,19,25)$. Identification of urate in an excavated skeleton (26) emphasizes the potential importance of the preparator. As that skeleton was only a few hundred years old, it is unclear if fossil materials could retain urate crystal deposits in a recognizable form. Classic gout erosions have been found in tyrannosaurs (27). Another form of crystalline arthritis, calcium pyrophosphate deposition disease is recognizable radiologically as giant subchondral geodes (cysts) and as deposition of calcium resulting in a sheet of calcium which parallels the articular surface or within intervertebral discs (3, $6,7,18)$.

\section{Spondyloarthropathy and Enthesopathy}

Spondyloarthropathy or reactive arthritis are terms applied to a group of disorders characterized by tendency to reactive new bone formation, asymmetrical pauciarticular peripheral joint erosions and ankylosis, and axial (spine and sacroiliac) joint disease $(3,6,7,28-30)$. Both marginal and subchondral erosions occur. The erosive disease is often unassociated with loss of peri-articular bone density, enabling it to survive taphonic forces in a recognizable form. Population analysis is essential with this group of disorders, as axial joint disease is not universal and the peripheral arthritis is occasionally polyarticular. Zygoapophyseal joint erosion or fusion and ossification within the annulus fibrosus (Fig. 5) are pathognomonic. Evidence of spondyloarthropathy abounds in the literature of human skeletal disease $(3,16,31,32)$, and the precedent for its non-human occurrence, reported (33).

While rheumatoid arthritis appears limited to humans (34), spondyloarthropathy is clearly represented among contemporary animals and in the fossil record $(35,36)$. Actually, spondyloarthropathy has a very long history, with geometric increase in frequency over geologic time (36). Trackable to the Paleocene (35), classic zygapophyseal joint changes even have been documented in a dinosaur (37).

Enthesial bone formation (ossification of sites of 


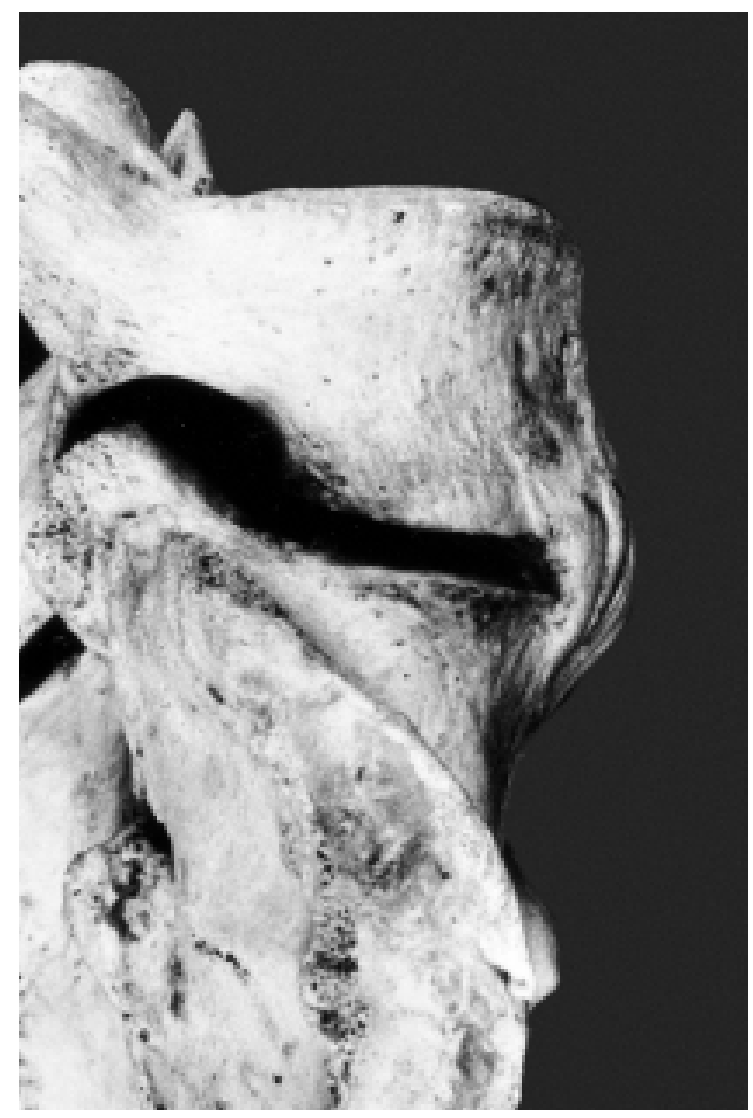

Figure 5 - Lateral view of Gorilla spine. Osseous bridging through anterior aspect of anulus fibrosus.

tendon, ligament, and joint capsule insertions), is highly suggestive of spondyloarthropathy, but not diagnostic. Diffuse idiopathic skeletal hyperostosis (DISH), ubiquitous among many groups of dinosaurs and older mammals $(2,38)$, is also characterized by enthesial bone formation $(3,6,7,39)$. Flowing ossification of spinal ligaments is found in DISH, as well as spondyloarthropathy. However, DISH does not affect the zygoapophyseal joints and sacroiliac joints, nor does it produce erosions. While DISH affects older mammals, other enthesial disorders [hypervitaminosis A (Fig. 6) and fluorosis] are not age dependent (40-42). Fluorosis is typically associated with diffuse osteosclerosis, irregular periosteal thickening and disorganization of osseous lamellar structure (in contrast to DISH which retains normal osteon relationships) $(38,43)$.

\section{Rheumatoid arthritis}

Rheumatoid arthritis contrasts with spondyloarthropathy by affecting the skeleton so symmetrically, that any asymmetry is cause for a reevaluation of the diagnosis $(3,6,7,44)$. It further differs from spondyloarthropathy by the associated loss of periarticular bony trabeculae, lack of significant reactive new bone formation or bony ankylosis and by sparing of axial joints (44-46). The erosions are marginal in distribution (47). The disorder has been identified in Indians dating back 6500 years $(48,49)$. The frequency of joint affliction both grossly and radiologically varies little from that noted in contemporary populations (5053). In contrast to spondyloarthropathy, rheumatoid arthritis has not been documented in any other animals.

\section{DIAGNOSTIC APPROACH AND HYPOTHESIS FORMATION}

Diagnosis of diseases of fossil bone requires the development of new criteria for diagnosis $(3,33,44$, 48,49 ). Utilization of such criteria (e.g., population frequency, sex ratio, radiologic appearance, pattern of involvement, nature of the lesions, and association with other disease features), often allows confirmation of a specific clinical diagnosis $(3,33,44$, $48,49)$. For this reason, ossuaries are usually not

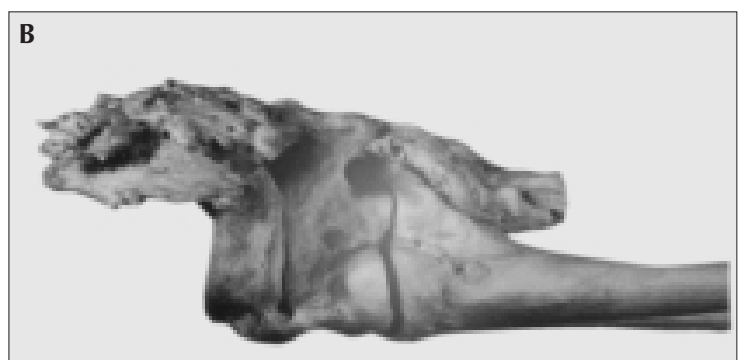

Figure 6 - Hypervitaminosis A affecting a zoological tiger. a. Lateral view of spine. Bulky osseous bridging of vertebrae centra and spinous processes, sparing the zygoapophyseal joints. B. Lateral view of midfoot. Enthesial osseous reaction results in ligamentous joint fusion. 
conducive to recognition of disease, only for its exclusion (dependent upon the completeness of skeletal representation). An exception is a ossuary study of osteoarthritis in fossil marsupials, in which osteoarthritis was limited in distribution to one joint (54). Although isolated examples of pathology are occasionally of value, placing them in perspective is enhanced through understanding the population they represent $(55,56)$.

Surveying for disease requires recognition of all changes which are not part of the normal condition of bone, and that each change be fully characterized (compatibility with the diagnosis being considered or does its presence infer an alternative diagnosis). Recording the presence and distribution of deviances from the normal state, instead of diagnosing them "in isolation", allows an epidemiologic approach. Examination of limited numbers of individuals from small sites similarly may be problematic, as disease mimicry can only be excluded on a population basis. Any population-based diagnostic effort must of course consider the the possibility that more than one disease may manifest in an individual or population. Comparison of occurrence of phenomena in different populations can proceed, only if the biases inherent in the deposit or acquisition of those populations can be identified.

The optimal technique for examination of specimens is non-destructive, easily accessible, and amenable to interpretation. Collaborative investigations by specialists in structure/function relationships (e.g., paleontologists) and specialists in disease (e.g., health care providers) should allow significant progress. While "pattern recognition" may document the diagnosis, more commonly a guess at the etiology will be the hypothesis to be proved or disproved. Given the large number of hypotheses amenable to testing, inability to test a hypothesis should perhaps stimulate its "back burner" position, until insight or technology provides a methodology for its testing.

\section{TECHNOLOGICAL ADVANCES FROM CHAIN SAWS TO RADIOLOGY}

The "great Texas chain saw massacre" destructive approach (Sally Shelton, personal communication) to the study of fossils, as exemplified by ground sections (57), has been complemented by techniques allowing three dimensional reconstruction of the derived information and also by techniques which often eliminate the need for destruction of the specimen. The sections or peals can be laserscanned to generate a digitalized image and regenerated from any angle. The data can be manipulated to "dissect away" portions. A three-dimensional image can even be generated of the structure of interest. Fiber optic light sources and optics can be passed through small apertures, allowing visualization of internal structures. The internal structures can also be visualized radiologically. Endocranial casts can be obtained without skull sectioning and sometimes even without specimen preparation! When sectioning is required, advances in microscopic technique minimize the requirement for thin grinding and allow more definitive identification of structures.

\section{Immunology}

Preservation of fossil materials is sometimes quite remarkable. While replacement does take place, structural morphology and even the actual constituent protein may be retained. Bone collagen has been detected in 200 million year old dinosaur bones (58), in Pleistocene avian and mammalian fossils $(59,60)$, and in 1.8 million YBP (year before present) human fossils (61). Collagen extracted from a frozen Elephas primigenius tusk (dated at 10,000 to 15,000 years) even retained (X-ray diffraction) its helical structure and sensitivity to collagenase denaturation $(59,60)$, Weser et al. (62) even reported survival of enzymatically active superoxide dismutase in a 3,000 year old mummy. Immunologic preservation, similar to histologic preservation, may be quite variable (63).

Collagen preservation has even been utilized to determine the premorbid environmental temperature of fossil specimens (64). Purified Pleistocene collagen was hydrolyzed and subjected to automated amino acid analysis $(65,66)$. Collagen hydroxyproline content in cold environment fishes and other vertebrates was found to be lower than that of their warm environment contemporaries $(67,68)$. Ho (69) found that two thirds of the variation in body temperature of mammalian species was explainable on the basis of relative collagen hydroxyproline content. Body temperature could be predicted at $19.5+0.198$ (hydroxyproline content per 1000 residues) or at $11.5+0.124$ (iminoacid content per 1000 residues). The iminoacids measured reflected the combined hydroxyproline and proline content. Body temperature increased 1 degree Centrigrade for each 5 hydroxyproline or 
9 iminoacid increase per 1000 aminoacid residues. The predicted 35.3 degree temperature of $N$. shastense (ground sloth) is comparable with the 34.5 noted in Choloepus hoffmanni (contemporary two-toed sloth). The predicted temperature for Canis dirus (37.2) is lower than that of the contemporary timber wolf (Canis lupus) (40.5), but comparable to that of the modern dog (36.7 40.6) (71).

Albumin phylogenetic structural alterations provides an excellent tool for fossil studies, as it is resistent to denaturation, is present in high concentration, and has been defined structurally in 2000 extant species (71-76). The amount extracted from frozen Mammuthus primigenius muscle was approximately 50 -fold less than that found on extraction of extant elephants (77). Antisera developed against it "reacted strongly" with albumin from extant elephants and only weakly with that from a sea cow. Postmortem albumin modification appeared responsible for the major differences, however.

\section{Microscopy}

Routine light and polarizing microscopy allow recognition of normal structure and its disruption. Bacteria (e.g., cyanobacteria) have been recognized histologically in 3.3 billion year old sediment (78). The first histologic studies were actually of fish $(12,79-81)$. Preservation of microscopic structure in animal bones was recognized by Schaffer in 1889 (82). Haversian canals have been recognized in bone and even in ossified tendons (Trachodon) $(83,84)$. Examination of 40-million YBP amberenclosed insects even revealed preservation of subcellular details $(85,86)$.

Immunologic techniques using specific antibodies allow recognition of intrinsic or extraneous antigens. Immunofluorescent technique utilizes an antibody which has been "labelled" with a chemical, which when excited by light of certain wavelengths gives off light of a different wavelength. A fluorescence microscope provides the excitatory light and registers the "excitement." Other immuno-histologic techniques are available but are limited in applicability to paleontologic applications by the background "coloration" of the specimen. One choses a technique with minimal background interference. If a background fluorescence is present at a given wavelength, an alternative immunofluorescent label is utilized (which fluoresces at a different wavelength, allowing it to be distinguished). While most immunofluorescence mi- croscopes utilize transmitted light, a reflected (epifluorescence) optical system can also be utilized. This is a surface technique requiring that only one surface of the specimen be available for analysis, rather than a thin ground section. If the appropriate tissue site is analyzed, if the antigen has survived, and if the approriate antisera is utilized, presence of the target antigen can be documented [e.g., antisera specific for treponemal disease (e.g., the non-venereal treponemal disease, yaws) detected its presence in an 11,500 YBP Arctodus (short-faced bear) (23)].

Scanning electron microscopes (SEM) are currently available with ports which will accept coffee cup-size specimens, minimizing specimen sacrifice. Specimens are typically coated (e.g., with gold) to enhance resolution and reduce charging (osseous structures are fairly non-conductive). Alacrity in the SEM procedure will sometimes permit avoidance of coating, essential if $\mathrm{x}$-ray diffraction (electron probe) techniques (which allow identification of contained elements and their relative concentrations) are to be applied. In contrast to extraction techniques, electron probe allows microscopic chemical localization. Ability to assess focal sites allows verification of a cystic structure as isolated from the external environment. Confidence that separation from the outside environment is complete was obtainable by noting a uniquely high sulfur content in a mosasaur spine wherein small abscesses were noted. Proof that the material was isolated eliminated the possibility of postmortum contamination and confidence that organisms seen were pertinent to the infection.

\section{DNA techniques}

Low concentrations of DNA, in variable states of preservation, have been extracted from paleontologic specimens ( $1 \%$ of that extractable from fresh muscle) $(60,87)$. DNA was recovered from a 40,000 year old frozen Siberian mammoth (85) and 25 million year old, amber-preserved insects (86). As yield of the extraction procedure is low and the DNA has not escaped modification, repair and replication are required for analysis. The extracted DNA is denatured, most efficiently by heating to 95-100 degrees Centigrade $(89,90)$, purified and replicated (by polymerase chain reaction techniques).

The Thermus aquaticus (Tac) heat-stable DNA polymerase chain reaction produces strands complementary to a defined DNA segment (91). Three to five minute thermal cycles are repeated 20-40 
times $(90,92)$. Heating separates the DNA strands, while cooling allows the polymerase to again utilize the separated strands to produce additional complementary sequences. As the number of DNA strands doubles with each cycle, a million-fold amplification may be obtained in as little as 4 hours (93).

Once sufficient DNA is replicated, it can be sequenced. Separated strands can be tested for homology with test DNA by assessing their ability to anneal. The more homologous the strands, the stronger their attraction and the greater the thermal stability of the resultant DNA hybrid. The degree of homology necessary for two strands of DNA to anneal is a condition of the temperature of the reaction $(91,94)$.

Contamination during excavation or by reagents/glassware must be considered. As paleontologic materials are not amplifiable beyond 150 base pair size, longer segments should be considered contaminants $(85,95)$. The antiquity of DNA is also verifiable because of resistant to enzymatic digestion (secondary to cross-linking), compared with modern contaminating materials (96). Amplification efficiency for antiquity DNA is inversely related to size, in contrast to similar sized contemporary DNA (98).

While Cytochrome oxidase I and NADH dehydrogenase I genes from Quagga mitochondrial DNA appeared to have two replacement nucleotide substitutions (compared to zebra) by the cloning technique $(87,99)$, the substitutions did not make sense. As these sites are conserved in all other tested vertebrates (97), common sense suggested and polymerase amplification verified it as artifact (97). The source of the artifact was the repair mechanisms of cellular DNA replication, introducing alternative nucleotides (95). Robbins et al. (89) found only 12 of 229 base pair mitochondrial sequences at variance with that of the contemporary mountain zebra. Alternative DNA sequences, coding for the same amino acid, accounted for 10 of the substitutions. This suggests that the two species were derived from a common ancester 3-4 million years ago. Fossil record implications are thus confirmed (100). Marx (101) reports that mammoth muscle mitochondrial DNA is "very similar" to that of the modern elephant. DNA, extracted from 17,000 ybp bison was identified as belonging to the Mycobacterium tuberculosis complex. Specific segment comparison revealed the organism to actually be Mycobacterium tuberculosis and not Mycobacterium bovis (21).

\section{Radiology}

Application of radiologic technical developments to the study of paleontology have opened new horizons for non-destructive analysis (101,1 02). Paperwrapped film, requiring high $\mathrm{x}$-ray exposures (often beyond that of routine museum equipment) has been replaced by a film screen technique. The latter utilizes phosphorescent screens (e.g., calcium tungstate) which give off packets of photons when exposed to a single $\mathrm{x}$-ray photon, thus substantially reducing the amount of radiation required for an exposure. Kodak Kodabrome IIRC F2M (normal contrast) black and white paper provides the desired contrast (103).

Scatter radiation, which reduces image contrast and resolution (104) can be reduced by use of grids (3, $6,105)$, airgaps $(105,106)$, or moving, tightly collimated photon beams (107-110). Grids are packs of parallel thin radiation-blocking materials placed perpendicular to the x-ray beam, thus blocking registry of scatter radiation. Technology developed for enhancement (e.g., Fourier transformations) of satellite photographs can now be applied to laserscanned radiologically images, producing digital enhancement (111-114). An inexpensive radiologic technique, tomography, can even "cut" the specimen, facilitating recognition of internal structures. Computerized axial tomograms (CAT scans) offer an eloquent approach to the same question, although the power output of this expensive equipment often must be "boosted" and the technique is limited in resolution.

Conroy and Vannier (115) utilized CAT in assessment of endocranial volume and intracranial relationships. The technique overcomes the problems of calcified matrix and taphonomy, reduces specimen preparation requirements and may even facilitate preparation by localization of critical components (116).

Resolution of a "clinical" CAT scan is only $1 \mathrm{~mm}$ at best (117), whereas X-ray techniques can offer $0.1 \mathrm{~mm}$ resolution. Microscopic CAT scanning, utilizing a 5 micrometer $\mathrm{x}$-ray beam source (FeinFocus, Wunstorf, FRG), is currently available on a limited basis (118). Mounting the specimen on a rotational stage even allows three-dimensional reconstruction of the images.

Magnetic resonance imaging or MRI produces cross sectional images of hydrated materials. Application requires access to the million dollar magnets and absence of magnetizable metals in the sample of interest. While applicability to paleontology may seem limited, frozen hydrated samples, 
such as Coelocanths have yielded new insights (Hans Peter Schultz, personal communication). Miocene whale vertebrae were also visualized by MRI, after protonation by placement in aqueous solution (119). The technique, however, cannot be blindly applied to assessment of relationships. Paleontologic specimens can be expected to induce non-uniform fields, a phenomena which which can significantly shift image position, distorting relationships (120).

\section{THREE-DIMENSIONAL IMAGING}

Three-dimensional representations, though providing novel insights, must be interpreted in light of their potential compromise by distortion and discontinuity artifact. Time intensive stacking techniques $(117,121,122)$ can now be pursued by direct conversion of two dimensional information (by Fourier transformation) to three dimensional images $(120,123)$, thus eliminating much of the artifact (120). However, the software is expensive and significant computer time is required for data acquistion, reconstruction and image manipulation. Areas of abrupt density change (e.g., bone interfaces) are not always accurately represented, because of averaging artifacts $(120,124)$. These imaging techniques do allow removal of portions of the structure, allowing visualization of selected interi- or structures from almost any angular perspective $(112,120,125-130)$ or display as a graded transparency manner $(120,131)$. Thus, specimens can be examined and internal relationships determined without matrix removal or specimen destruction/damage (120, 132-134). Microscopy, utilizing laser scanning techniques, is also amenable to tomography and three-dimensional reconstruction (135). Three dimensional images of CAT scans and MRI images and even fossil cephalopods can be recorded on holographs with sufficient accuracy for measurement of object relationships (136138). Physical models, accurate in three-dimensions, can even be computer-generated (139).

\section{PERSPECTIVE}

The future of paleorheumatology lies in concerted coordinated efforts to expand speculation to form testable hypotheses and then to identify valid techniques for testing them. If a testable hypothesis cannot be generated, perhaps the problem should be placed on hold or an interdisciplinary council developed for input as to application of new technologies to their assessment. Epidemiologic approaches are essential. While isolated finds are occasionally of value, placing them in perspective usually requires an understanding of the population they represent.

\begin{abstract}
SUMMARY
As paleopathology has evolved from observational speculation to analysis of testable hypotheses, so too has recognition of its contribution to vertebrate paleontology. In the presence of significant structural and density variation (between matrix and osseous structures), x-rays provide an additional perspective of osseous response to stress and disease. As film techniques are time and cost expensive, fluoroscopy has proven a valuable alternative. Radiologic techniques also allow non-invasive "sectioning" of specimens, illustrating significant internal detail. The object can be "split" on a plane and the two portions rotated to "open" the image. This three-dimensional approach now can be applied to other forms of sequential data to their facilitate 3-dimensional representation graphically or with solid representations.

Antigen and microstructure may be well preserved in fossils. Molecular preservation with retention of helical structure and sensitivity to collagenase has been demonstrated in 10,000 year old collagen. Antigen has been extracted from 100 million year old bone and documented, in situ, in 11,000 year old bone. If the appropriate site in the tissue is assessed, if antigen is still present, and if the appropriate antisera is utilized, fixation of the antibody to the specimen can be detected. Minute amounts of DNA can be amplified and analyzed. Recovery of DNA from a 40,000 year old mammoth, 17,000 year old bison and from 25 million year old insects provides opportunity for cloning and independent assessment of relationships. Implications of available technology focuses direction for development of collaborative approaches.
\end{abstract}

Parole chiave - Paleopatologia, spondiloartite, artrite reumatoide, gotta, tubercolosi.

Key words - Paleopathology, spondyloarthropathy, rheumatoid arthritis, gout, tubercolosis. 


\section{REFERENCES}

1. Moodie RL. Paleopathology: An Introduction to the Study of Ancient Evidences of Disease. Urbana, University of Illinois, 1923.

2. Rothschild BM, Berman D. Fusion of caudal vertebrae in late Jurassic sauropods. J Vert Paleontol 1991; 11: 29-36.

3. Rothschild BM, Martin L. Paleopathology: Disease in the Fossil Record. London, CRC Press, 1993.

4. Rothschild BM, Sebes JI, Rothschild C. Antiquity of arthritis: Spondyloarthropathy identified in the Paleocene of North America. Clin Exp Rheum 1998; 16: 573-5.

5. Rothschild BM, Witzke BJ, Hershkovitz I. Metastatic cancer in the Jurassic. Lancet 1999; 354: 398.

6. Rothschild BM. Rheumatology: A Primary Care Approach. New York, Yorke Medical Press, 1982.

7. Resnick D, Niwayama G. Diagnosis of Bone and Joint Disorders. 2nd ed. Philadelphia, Saunders, 1988.

8. Fiennes RN. Report of the pathologist for the year 1960.Proc Zool Soc London 1961; 137: 173-96.

9. Rothschild BM, Woods RJ, Turner KR. Evaluation of erosive arthritis in antiquity. J Rheumatol 1989; 16: 1012-3.

10. Woods RJ, Rothschild BM. Population analysis of symmetrical erosive arthritis in Ohio Woodland Indians (1200 years before the present time). J Rheumatol 1988; 15: 1258-63.

11. Ascenzi A, Silvestrini G. Bone-boring marine microorganisms: An experimental investigation. J Human Evolution 1984; 13: 531-6.

12. Ascenzi A. Microscopy and prehistoric bone. In: Science and Archaeology: A comprehensive Survey of Progress and Research. (Ascenzi A, ed). New York, Basic Books, 1963: 526-38.

13. Garland AN. A histological study of archaeological bone decomposition. In: Death, Decay and Reconstruction: Approaches to Archaeology and Forensic Science (Boddington A, Garland AN, Janaway RC, eds). Manchester University Press, 1987: 121-6.

14. Hackett CJ. Microscopical focal destruction (tunnels) in exhumed human bones. Medicine Science and Law 1981; 21: 243-65.

15. Henderson J. Factors determining the state of preservation of human remains. In: Death, Decay and Reconstruction: Approaches to Archaeology and Forensic Science (Boddington A, Garland AN, Janaway RC, eds). Manchester University Press, 1987: 43-54.

16. Wells C. Pseudopathology. In: Diseases in Antiquity (Brothwell DR, Sandison AT, eds). Illinois, Charles C Thomas, 1967: 5-19.

17. Milner GR, Smith VG. Carnivore alteration of human bone from a late prehistoric site in Illinois. Am J Phys Anthropol 1989; 79: 43-9.

18. Genant HK. In: Arthritis and Allied Conditions (McCarty DJ, ed), 10th ed., Philadelphia, Lea and Febiger, 1985: 76-147.

19. Jaffe HL. Metabolic, Degenerative, and Inflamma- tory Diseases of Bone and Joints. Philadelphia, Lea and Febiger, 1972.

20. Martin LD, Rothschild BM. Frequency of pathology in a large natural sample from Natural Trap Cave (late Pleistocene). J Vert Paleontol 1989; 9: 31A.

21. Rothschild BM, Martin LD, Lev G, Bercovier H, Bar-Gal GK, Greenblatt C, Donoghue H, Spigelman M, Brittain D Mycobacterium-tuberculosis-complex DNA from an extinct bison dated 17,000 years bp. Clin Infect Dis 2001; 33: 305-11.

22. Rothschild BM, Rothschild C. Treponemal disease revisited: Skeletal discriminators for Yaws, Bejel, and venereal syphilis. Clin Infect Dis 1995; 20: 1402-8.

23. Rothschild BM, Turnbull W. Treponemal infection in a Pleistocene bear. Nature 1987; 329: 61-2.

24. Rothschild BM, Heathcote GM. Characterization of the skeletal manifestations of the treponemal disease Yaws as a population phenomenon. Clin Infect Dis 1993; 17: 198-203.

25. Rothschild BM, Heathcote GM. Characterization of gout in a skeletal population sample: Presumptive diagnosis in Micronesian population. Amer J Phys Anthropol 1995; 98: 519-25.

26. Rogers J, Watt I, Dieppe P. The paleopathology of rheumatic diseases. Clin Rheum 1985; 5: 15.

27. Rothschild BM, Tanke D, Carpenter K. Tyrannosaurs suffered from gout. Nature 1997; 387: 357.

28. Bywaters E. The early radiologic signs of rheumatoid arthritis. Bull Rheum Dis 1960; 11: 231-4.

29. Martel W. Radiologic signs of rheumatoid arthritis with particular reference to the hand, wrist, and foot. Med Clin N Amer 1968; 52: 655-65.

30. Rothschild BM, Woods RJ. Spondyloarthropathy: Erosive arthritis in representative defleshed bones. Am J Phys Anthropol 1991; 85: 125-34.

31. Ruffer MA. Studies in the Palaeopathology of Egypt. Chicago, University of Chicago Press, 1921: 184-93.

32. Zorab PA. Historical and prehistorical background of ankylosing spondylitis. Proc Roy Soc Med 1961; 54 : 415-20.

33. Rothschild BM, Woods RJ. Spondyloarthropathy in gorillas. Semin Arthritis Rheum 1989; 18: 267-76.

34. Rothschild BM. Rheumatoid arthritis at a time of passage. J Rheumatol 2001; 28: 245-50.

35. Rothschild BM, Tanke D, Hershkovitz I, Schultz M. Mesozoic Neoplasia: Origins of Hemangioma in the Jurassic. Lancet 1998; 351: 1862.

36. Rothschild BM, Prothero DR, Rothschild C. Origins of spondyloarthropathy in Perissodactyla. Clin Exp Rheum 2001; 19: 629-32.

37. Rothschild BM, Helbling M II, Miles C. Origin of spondyloarthropathy in the Jurassic. Lancet (in press).

38. Rothschild BM. Diffuse idiopathic skeletal hyperostosis as reflected in the paleontologic record: Dinosaurs and early mammals. Semin Arthritis Rheum 1987; 17: 119-25.

39. Rothschild BM. Diffuse idiopathic skeletal hyperos- 
tosis: Misconceptions and reality. Clin Rheum 1985; (9/10): 207-211.

40. Pennes DR, Martel W, Ellis CN. Retinoid-induced ossification of the posterior longitudinal ligament. Skel Radiol 1985; 14: 191-3.

41. Seawright AA, English. Hypervitaminosis A and deforming cervical spondylosis of the cat. J Comp Path 1967; 77: 29-43.

42. Singh A, Dass R, Singhhayreh S, Jolly SS. Skeletal changes in endemic fluorosis. J Bone Joint Surg 1962; 44B: 806-15.

43. Faccini JM, Teotia SP. Histopathological assessment of endemic skeletal fluorosis. Calcif Tissue Int 1974; 16: 45-57.

44. Rothschild BM, Woods RJ, Ortel W. Rheumatoid arthritis "in the buff": Erosive arthritis in defleshed bones. Am J Phys Anthropol 1990; 82: 441-449.

45. Bogoch E, Gschwend N, Bogoch B, Rahn B, Perren S. Juxta-articular bone loss in experimental inflammatory arthritis. J Orthop Res 1988; 6: 648-56.

46. Ropes MW, Bennett GA, Cobb S, Jacox R, Jessar RA. 1958 revision of diagnostic criteria for rheumatoid arthritis. Bull Rheum Dis 1958; 9: 175-6.

47. Weissberg DL, Resnick D, Taylor A, Becker M, Alazraki N Rheumatoid arthritis and its variants: Analysis of scintiphotographic, radiographic, and clinical examinations. Am J Roent 1978; 131: 665-73.

48. Rothschild BM, Turner KR, DeLuca MA. Symmetrical erosive peripheral polyarthritis in the Late Archaic Period of Alabama. Science 1988; 241: 1498-501.

49. Rothschild BM, Woods RJ. Symmetrical erosive disease in Archaic Indians: The origin of rheumatoid arthritis in the New World. Semin Arthritis Rheum 1990; 19: 278-84.

50. Fletcher DE, Rowley KA. The radiologic features of rheumatoid arthritis. Br J Radiol 1952; 25: 282-95.

51. Martio J, Kiviniemei P, von Essen R. Early rheumatoid arthritis in the USSR and in Finland. Scand J Rheum 1980; 9: 39-43.

52. Medsger TA Jr, Masi AT. Epidemiology of the rheumatic diseases. In: Arthritis and Allied Conditions, (McCarty DJ, ed), 10th ed, Philadelphia: Lea and Febiger, 1985, 9-39.

53. Moran H, Chen S-L, Muirden KD, Jiang S-J, Gu Y$\mathrm{Y}$, Hopper J, et al. A comparison of changes seen on radiographs of rheumatoid arthritis patients in Australia and in China. Arthritis Rheum 1987; 30: 1298-302.

54. Rothschild BM, Molnar R. Osteoarthritis in fossil marsupial populations of Australia. Ann Carnegie Museum 1988; 57: 155-8.

55. Paine RR. Model life table fitting by maximum likelihood estimation: a procedure to reconstruct paleodemographic characteristics from skeletal age distributions. Am J Phys Anthropol 1989; 79: 51-61.

56. Rothschild B, Rothschild C. Nineteenth century spondyloarthropathy independent of socioeconomic status: Lack of skeletal collection bias. J Rheumatol 1993; 20: 314-9.
57. Bjerring HC. Morphological observations on the exoskeletal skull roof of an osteolepiform from the Carboniferous of Scotland. Acta Zool 1972; 53: 73-92.

58. Wyckoff RW. Collagen. In: Biogeochemistry of Amino Acids, (Hare PE ed), New York: Wiley, 1980: 17

59. Randall JT, Fraser RD, Jackson S, Martin AW, North AC. Aspects of collagen structure. Nature 1952; 169: 1029-33.

60. Rowley MJ, Rich PV. Immunoreactive collagen in avian and mammalian fossils. Naturwissenschaften 1986; 73: 620-2.

61. Lowenstein JM. Immunological reactions from fossil material. Philos Trans R Soc London B 1981; 292: 143-9.

62. Weser U, Miesel R, Hartmann H-J. Mummified enzymes. Nature 1989; 341: 696.

63. Oakley KP. The associated implements and mammalian remains and the composition of the hominoid remains. British Mus Nat History Bull Geology 1955; 2: $254-65$.

64. Ho TY. The amino acid composition of bone and tooth proteins in late Pleistocene mammals. Proc Natl Acad Sci USA 1965; 54: 26-31.

65. Piez KA, Morris L. A modified procedure for the automatic analysis of amino acid. Anal Biochem 1960; 1: 187-201.

66. Sanger F, Thompson EO. Halogenation of tyrosin during acid hydrolysis. Biochem Biophys Acta 1963; 71: 468-71.

67. Gustavson KH. The function of hydroxyproline in collagens Nature 1955; 175: 70-4.

68. Leach AA. The amino acid composition of amphibian, reptile and avian gelatin. Biochem J 1957; 67: 83-7.

69. Ho T-Y. Mammalian bone collagen and body temperature as a basis for estimation of body temperature of prehistoric mammals. Heredity 1974; 32: 1139.

70. Spector WS. Handbook of Biological Data. Philadelphia, Saunders, 1956: 343.

71. Ibrahimi IM, Prager EM, White TJ, Wilson AC. Amino acid sequence of California quail lysozyme. Effect of evolutionary substitutions on the antigenic structure of lysozyme. Biochemistry 1979; 18: 273644.

72. Nakanishi M, Wilson AC, Nolan RA, Gorman GC, Bailey GS. Phenoxyethanol: protein preservation for taxonomists. Science 1969; 163: 681-3.

73. Peters T Jr. Serum albumin. In: The Plasma Proteins - Structure, Function, and Genetic Control, (Putnam FW, ed), 2nd ed. New York: Academic Press, 1975: 133-81.

74. Sarich VM.. Albumin phylogenetics. In: Albumin Structure, Function and Uses, (Rosenoer VM, Oratz M, Rothschild MA, eds), Oxford, Pergamon, 1977: 85-111.

75. Sensabaugh GF, Wilson AC, Kirk PL. Protein stability in preserved biologic remains. 1. Survival of 
histologically active proteins in an 8 year old sample of dried blood. Int J Biochem 1971; 2: 545.

76. Wilson AC, Carlson SS, White TJ. Biochemical evolution. Annual Rev Biochem 1977; 46: 573.

77. Prager EM, Wilson AC, Lowenstein JM, Sarich VM. Mammoth albumin. Science 1980; 209: 287-289.

78. Schopf JW, Packer BM. Early Archean (3.3-billion to 3.5-billion-year-old) microfossils from Warrawoona Group, Australia. Science 1987; 237: 70-3.

79. Pander CH. Monographie der fossilen Fische des silurischen Systems der russisch-baltischen Gouvernements. St. Petersburg, Buchdruk d keis Akad d Wiss, 1856.

80. Romer AS. Bone in early vertebrates. In: Bone Biodynamics, (Frost HM, ed), Boston: Little Brown, 1964, 13-37.

81. Williamson W. On the microscopic structure of the scales and dermal teeth of some ganoid and placoid fish. Phil Trans Roy Soc London 1849; 140: 43575.

82. Uber den Feineren Bau Fossiler Knochen. Sitzungsberichte der Kaiserlichen Akademie der Wissenschaften, Vienna, Mathematisch-Naturwissenschaftliche 1889; 98: 319-82.

83. Broili F. Uber den feineren Ban der "Verknocherten Sehnen" (=Verknocherten Muskeln) von Trachodon. Anat Anz 1922; 55:465-75.

84. Dollo L. Note sur les ligaments ossifies des dinosauriens de Bernissart. Arch Biol 1887; 7: 249-64.

85. Paabo S. Ancient DNA: Extraction, characterization, molecular cloning, and enzymatic amplification. Proc Natl Acad Sci 1989; 86: 1939-43.

86. Poinar GO, Hess R. Ultrastructure of 40-millionyear-old insect tissue. Science 1982; 215: 1241-2.

87. Higuchi R, Wilson AC. Recovery of DNA from extinct species. Fed Proc 1984; 43: 1557.

88. Higuchi R, Bowman B, Freiberger M, Ryder OA, Wilson AC. DNA sequences from the quagga, an extinct member of the horse family. Nature 1984; 312 : $282-4$

89. Robbins J, Rosteck P Jr, Haynes JR, Freyer G, Cleary ML, Kalter HD, et al. The isolation and partial characterization of recombinant DNA containing genomic sequences from the goat. J Biol Chem 1979; 254: 6187-95.

90. Schochetmann G, Ou C-Y, Jones WK. Polymerase chain reaction. J Infect Dis 1988; 158: 1154-69.

91. Saiki RK. Primer-directed enzymatic amplification of DNA with a thermostable DNA polymerase. Science 1988; 239: 487-94.

92. Mullis KB, Faloona FA. Specific synthesis of DNA in vitro via a polymerase-catalyzed chain reaction. Methods Enzymol 1987; 155: 335-50.

93. Landegren U, Kaiser R, Caskey CT, Hood L. DNA diagnostics -molecular techniques and automation. Science 1988; 242: 229-37.

94. Shoemaker SA, Fisher JH, Scoggin CH. Techniques of DNA hybridization detect small numbers of mycobacteria with no cross-hybridization with non-my- cobacterial respiratory organisms. Am Rev Resp Dis 1985; 131: 760-3.

95. Paabo S, Higuchi RG, Wilson AC. Ancient DNA and the polymerase chain reaction. J Biol Chem 1989; 264: 9709-12.

96. Doran GH, Dickel DN, Ballinger WE Jr, Agee OF, Laipis PJ, Hauswirth WW. Anatomical, cellular and molecular analysis of 8,000-year-old human brain tissue from the Windover archaeological site. Nature 1986; 323: 803-6.

97. Paabo S, Wilson AC. Polymerase chain reaction reveals cloning artifacts. Nature 1988; 334: 387-8.

98. Paabo S, Gifford JA, Wilson AC. Mitochondrial DNA sequences from a 7000-year old brain. Nucleic Acids Res 1988; 16: 9775-7.

99. Higuchi RG, Wrischnik LA, Oakes E, George M, Topng B, Wilson AC. Mitochondrial DNA of the extinct quagga: Relatedness and extent of postmortem changes. J Mol Evol 1987; 25: 283-7.

100. George M, Ryder OA. Mitochondrial DNA evolution in the genus Equus. Genetics 1983; 104: 27S.

101. Marx JL. Multiplying genes by leaps and bounds. Science 1988; 240: 1408-10.

102. Horner JR, Weishampel DB. A comparative embryological study of two ornithischian dinosaurs. Nature 1988; 332: 256-7.

103. Fairgrieve SI, Bashford J. A radiographic technique of interest to physical anthropologists. Am J Phys Anthropol 1988; 77: 23-6.

104. Floyd CE, Beatty PT, Ravin CE. Scatter compensation in digital chest radiography using Fourier deconvolution. Invest Radiol 1989; 24: 30-3.

105. Rothschild BM, Sebes JI, DeSmet AA. Radiologic assessment of bone and joint disease. I. Magnification radiology. Semin Arthritis Rheum 1985; 14: 274-9.

106. Sorenson JA, Floch J. Scatter rejection by air gaps: An empirical model. Med Phys 1985; 12: 308-16.

107. Plews DB. A scanning system for chest radiography with regional exposure control: Theoretical considerations. Med Phys 1983; 10:646-54.

108. Plews DB, Vogelstein E. A scanning system for chest radiography with regional exposure control: Practical implementation. Med Phys 1983; 10: 655-63.

109. Sorenson JA, Nelson JA, Niklason LT, Jacobsen SC. Rotating disk device for slit radiography of the chest. Radiology 1980; 134: 227-31.

110. Barnes GT, Brezovich IA, Witten DM. Scanning multiple slit assembly: A practical and efficient device to reduce scatter. Am J Radiol 1977; 129: 497 501.

111. Boone JM. Scatter correction algorithm for digitally acquired radiographs: Theory and results. Med Phys 1986; 13: 319-28.

112. Artzy E, Frieder G, Herman GT. The theory, design, implementation and evaluation of a three-dimensional surface detection algorithm. Comput Graphics Image Processing 1980; 15: 1-24.

113. Naimuddin S, Hasegawa B, Mistretta CA. Scatter- 
glare correction using a convolution algorithm with variable weighting. Med Phys 1987; 14: 331-4.

114. Shaw CG, Ergun DL, Myerowitz PD. A technique of scatter and glare correction for videodensitometric studies in digital subtraction videoangiography. Radiology 1982; 142: 209-13.

115. Conroy GC, Vannier MW. Endocranial volume determination of matrix-filled fossil skulls using highresolution computed tomography. In: Hominid Evolution: Past, Present and Future, Lawrence, Alan R. Liss, 1985: 419-26.

116. Skinner MF, Sperber Gh. Atlas of Radiographs of Early Man. New York, Liss, 1983.

117. Poelmann RE, Verbout AJ. Computer-aided three-dimensional graphic reconstructions in a radiological and anatomical setting. Acta Anat 1987; 130: 132-6.

118. Layton MW, Goldstein SA, Goulet RW, Feldkamp LA, Kubinski DJ, Bole GG. Examination of subchondral bone architecture in experimental osteoarthritis by microscopic axial tomography. Arthritis Rheum 1988; 31: 1400-5.

119. Sebes JI, Langston JW, Gavant ML, Rothschild BM. MR imaging of growth recovery lines in fossil vertebrae. Am J Roentgenol 1991; 157: 415-6.

120. Farrell EJ, Zappulla RA. Three-dimensional data visualization and biomedical applications. CRC Critical Reviews in Biomedical Engineering 1989; 16: 323-63.

121. Feldkamp LA, Goldstein SA, Parfitt AM, Jesion G, Kleerekoper M. The direct examination of three-dimensional bone architecture in vitro by computed tomography. J Bone Mineral Res 1989; 4: 3-11.

122. Johnson EM, Capowski JJ. A system for the threedimensional reconstruction of biological structures. Comp Biomed Res 1983; 16: 79-87.

123. Hadley MN, Sonntag VK, Amos MR, Hodak JA, Lopez LJ. Three-dimensional computed tomography in the diagnosis of vertebral column pathological conditions. Neurosurgery 1987; 21: 186-92.

124. Moseley ME, White DL, Wang S-C, Wikstrom M, Gobbel G, Roth K. Stereoscopic MR imaging. J Comput Assist Tomography 1989; 13: 167-73.

125. Artzy E, Herman GT. Boundary detection in three dimensions with a medical application. Comput Graphics Image Processing 1981; 15: 92-136.

126. Farrell EJ. Color display and interactive interpretation of three-dimensional data. IBM J Res Dev 1983; 27: 356-66.
127. Frank J. Three-dimensional imaging techniques in electronmicroscopy. BioTechniques 1989; 7: 16473.

128. Totty WG, Vannier MV. Complex musculoskeletal anatomy: Analysis using three dimensional surface reconstruction. Radiology 1984; 150: 173-7.

129. Virapongse C, Shapiro M, Gmitro A, Sarwar M. Three-dimensional computed tomographic reformation of the spine, skull, and brain from axial images. Neurosurgery 1986; 18: 53-8.

130. Woolson ST, Dev P, Fellingham LL, Vassiliadis A. Three-dimensional imaging of bone from computerized tomography. Clin Orthop Rel Res 1986; 202 : 239-48.

131. Batnizky S, Price HI, Lee KR, Cook PN, Cook LT, Fritz SL, et al. Three-dimensional computer reconstructions of brain lesions from surface contours provided by computed tomography: A prospectus. Neurosurgery 1979; 11: 73-84.

132. Jiminez J, Santisteban A, Carazo JM, Carrascosa JL. Computer graphic display method for visualizing three-dimensional biological structures. Science 1986; 232: 1113-5.

133. Marx M, D'Auria SH. Three-dimensional CT reconstructions of an ancient human Egyptian mummy. Am J Radiol 1988; 150: 147-9.

134. Mazziotta JC, Hamilton BL. Three-dimensional computer reconstruction and display of neuronal structure. Comput Biol Med 1977; 7: 265-79.

135. Takamatsu T, Fujita S. Microscopic tomography by laser scanning microscopy and its three-dimensional reconstruction. J Microsc 1988; 149: 167-74

136. Benatar M, Wynchank S, Adams LP. Three-dimensional magnetic resonance image representation using reflection holography. Phys Med Biol 1988; 33: 1469-72.

137. Fujioka M, Ohyama N, Honda T, Tsujinchi J, Suzuki M, Hashimoto S, et al. Holography of 3-D surface reconstructed CT images. J Comput Assist Tomograph 1988; 12: 175-8.

138. Illert CR, Reverberi D. Holography reveals the soft anatomy of ancient cephalopods. Bull Math Biol 1988; 50: 19-34.

139. Sato AG, Yasuda M, Sato Y, Nakamae E. Stereographic semitransparent images reconstructed by computer graphics from serial microscopic sections. In: Science on Form, (Ishizaka S, ed), Tokyo, KTK Publishers, 1986: 305-11. 